\title{
Mapping the Historical Development and Perceptions of Democratic Elections in China Since 1949
}

\section{Zhaohui Hong ${ }^{1}$}

'Fordham University, USA

\begin{abstract}
One of the key measures for reforming the Chinese political system is to establish the checks and balances within the Communist Party. Doing so in turn requires an open, competitive and comprehensive democratic intraparty election. This article focuses on the historical development of intraparty elections and the practice of a checks-and-balances system in China since 1949. The article examines five main perceptions of the current political situation in China, including the urgent need to hold intraparty elections, the necessity of implementing the multi-candidate election, the positive impact of competitive elections and effective supervision mechanism, the capability of tolerating competitive interest groups within the party, and the integration of the state and party policies on building a people-oriented harmonious society. The article argues that building a democratic mechanism is contingent upon competition, which requires public campaign and transparent elections. Only in this way will the Chinese Communist Party prove itself to be adaptable and resilient.
\end{abstract}

Keywords: Chinese communist party, Intra-party elections, Checks and balances, Political reform, Competitive election, Effective supervision.

JEL Classification: K16; K19; Z10; P48; P16.

Citation | Zhaohui Hong (2019). Mapping the Historical Development and Perceptions of Democratic Elections in China since 1949. Asian Journal of Social Sciences and Management Studies, 6(1): 7-14.

History:

Received: 25 January 2019

Revised: 28 February 2019

Accepted: 6 March 2019

Published: 20 May 2019

Licensed: This work is licensed under a Creative Commons

Attribution 3.0 License (cc) EY

Publisher: Asian Online Journal Publishing Group
Funding: The author would like to thank the University of Macau Research Fund for funding this research project, and thank Zhidong Hao, Yi Sun, Lu Cao, Jianfeng Jin, Shushu Qian, and Emma Hong for their suggestions and assistance.

Competing Interests: The author declares that there are no conflicts of interests regarding the publication of this paper.

Transparency: The author confirms that the manuscript is an honest, accurate, and transparent account of the study was reported; that no vital features of the study have been omitted; and that any discrepancies from the study as planned have been explained.

Ethical: This study follows all ethical practices during writing.

\section{Contents}

1. Introduction

2. Research Methodology

3. Mapping Chinese Communist Party's Internal Elections Since 1949

4. The Perceptions of Competitive Elections within the Chinese Communist Party …..........................................................9

5. Conclusion

References 


\section{Introduction}

As one of the key indications of the successful Chinese political system, the checks and balances within the Chinese Communist Party (CCP) is critical. This requires an open, competitive and comprehensive democratic election. Deng Xiaoping once said, "The essential question is election, for both the party and the state" (Deng, 1994). This article focuses on the historical study of intraparty elections and building a checks-and-balances system in China since 1949.

The article will examine five main perceptions of the current political situation in China, which can be summarized as follows: 1) the urgent need to hold intraparty elections; 2) the necessity of implementing the multicandidate election; 3) the positive impact of competitive elections and effective supervision mechanism; 4) the capability of tolerating competitive interest groups within the party; and 5) and the integration of the state and party policies on building a people-oriented harmonious society. The article will argue that, logically, building a democratic mechanism is contingent upon competition, which in turns requires public campaign and transparent elections. Only in this way will the CCP prove itself to be adaptable and resilient (Nathan, 2003).

\section{Research Methodology}

This study uses the mixed method in conducting empirical research and examining a large quantity of secondary sources. Adopting the "sandwich" research method (Frechtling and Sharp, 2007) a first round of preliminary and qualitative interviews were conducted with fifteen CCP officials and scholars in an effort to understand their opinions through the written questionnaires and interview questions. These conversations took place from June to December 2011, primarily via phone, email and face-to-face interviews.

The second phase involved a quantitative study of $30 \mathrm{CCP}$ officials and scholars through a written survey designed to discern their views on the current situation, problems and directions of the intra-party reform. It took place from January to March 2012, in the U.S., Beijing, Hong Kong, Shanghai, and Zhejiang province, where the interviewees filled out questionnaires on site or via email correspondence.

The third and final phase of the research consisted of a second round of qualitative in-depth interviews which took place from March to December of 2012 in Beijing, Shanghai, Zhejiang, Hong Kong, Macau and the U.S. The interview questions were mailed in advance to the participants so that they could make due preparations prior to the personal interviews.

The participants in these interviews and surveys included current officials at the level of department secretary, retired officials and prominent scholars. In order to protect their identity and privacy, each of the twenty-two participants is denoted with a number. The seven main topics are identified with a capital letter, and each sub-topic is marked with a number. For instance, the answer provided by participant no. 1 is indicated by 1-G-1. The time of each interview is noted, but the specific place is omitted.

\section{Mapping Chinese Communist Party's Internal Elections Since 1949}

According to Qian Gang, "intraparty democracy" has become a key term in the CCP's prominent publications over the past decade. In 2009, over 150 articles published by the People's Daily used the term "intraparty democracy," almost a four-fold increase from 2003. The popular website Baidu also saw a 13 times increase in the number of articles that used the term "intraparty democracy" between 2003 and 2007 (Qian, 2012).

In an effort to study the reforms within the CCP, it is essential to accurately understand the history and current situation of the CCP's internal elections. Since 1949, the CCP's democratic elections and the intra-party checks and balances have shown some positive signals, though there has not been any substantial progress.

The first signal appeared in September 1956 at the Eighth National Congress of the CCP when the CCP proposed to expand intra-party democracy, improve transparency of party affairs, establish a permanent system for party congress, develop intra-party supervision, institutionalize a term limited system for leadership positions, and protect the democratic rights of party members (Liu, 1956). However, the anti-rightist movement in 1957 interrupted the process of the proposed party reform. In particular, the Lushan Conference in 1959 conducted massive ruthless persecution against Peng Dehuai who expressed different political opinions within the party.

The second initiation of intra-party democracy was born at a special conference from January 11 to February 7 , 1962, the so-called "Seven Thousand People Conference." Mao Zedong made an unprecedented self-criticism at the conference, emphasizing his opposition to personal arbitrariness and decisive decisions without group consultations. The meeting stressed the need to supervise and check the CCP leaders at all levels (Zhang, 2006). However, the "Four Purifications" movement again capitalism in 1964 and the Cultural Revolution in 1966 led to the emergence of an authoritarian dictatorship and a more brutal persecution of dissident groups against Liu Shaoqi, Deng Xiaoping and others.

The third dawn was ignited by the Third Plenary Session of the Eleventh CCP Central Committee in 1978. The conference initiated the process of modernization of contemporary China and the CCP itself. In 1981, the Sixth Plenary Session of the Eleventh Central Committee of the CCP adopted the "Resolution on Several Historical Issues of the Party since the Founding of the People's Republic of China," emphasizing that the CCP's power is excessively concentrated on individuals. Thus, the CCP must oppose the personal arbitrariness and individual worship (TCCoCCP, 1981). However, the anti-spiritual pollution and anti-liberalization movement in 1986 purged the intra-party democratic forces headed by Hu Yaobang, and the third round of the CCP's internal democracy was extinguished.

The fourth emergence of pro-democratic efforts was reflected in the 1987 report of the 13th CCP's National Congress because the CCP first proposed the separation of party and government and comprehensively promoted its political reform (Zhao, 1987). However, the June 4th incident of 1989 interrupted the CCP's democratic reforms, and the party's pro-democratic forces headed by Zhao Ziyang were again persecuted (Shi, 1990; Burns, 1999).

Since the 21 st century, the CCP's important reports and regulations have proposed some new ideas and new directions. For example, the Report of the 16th CCP's National Congress in 2002 put forward that "the intra-party democracy is the life of the party" (Jiang, 2002). Also, its "Decision on Strengthening the Construction of the Party's Governing Capability" was adopted by the Fourth Plenary Session of the 16th CCP's Central Committee in 
2004, proposing "gradual expansion of direct election to the local levels of party organizations" (TCCoCCP, 2004). Furthermore, "The Regulations on Intra-Party Supervision of the Communist Party of China (Trial)," issued in 2004, clearly stipulated the implemented measures for "strengthening intra-party supervision and developing intraparty democracy" (TCCoCCP, 2005). Similarly, the CCP in 2006 issued "The Rights Protection Regulations for CCP Members" which protected party members' different political opinions within the party (TCCoCCP, 2007). In 2007, the Report of the 17th CCP's National Congress authorized party members as the main authority of the CCP and proposed the separation of the three powers with the CCP's characteristics: power of decision-making, power of execution, and power of supervision (Hu, 2007). In addition, the Provisional Regulations on the Tenure System of Representatives of the CCP's National Congress and Local Representatives, in 2008, emphasized the role of representatives of party congresses at all levels (TCCoCCP, 2008). Meanwhile, Xi Jinping stated in 2010 that the power should be authorized by the people and should serve to the people, clearly acknowledging the fundamental source and foundation of power (Xi, 2010). In 2012, the Report of the 18th CCP's National Congress added a special chapter on political reform, re-emphasizing its interest and attention to political reform (Hu, 2012).

It must be pointed out though that the leaders of the CCP often set up the restrictions for China's democracy, such as banning multi-party rotations, diversified leading ideology, separation of the three powers favored by the West, federalism, and privatization, etc ( Wu, 2011). In particular, Xi Jinping eliminated the term limit for the China's presidency in 2018 by aggressively revising the Chinese Constitution (People's Congress, 2018). However, the CCP never treated democratic elections as a restricted issue and never resolutely opposed it in public. Democratic election is a form of political governance that the CCP has practiced more or less since its founding.

In terms of the specific implementation of intra-party democracy, since the 1980s, the CCP has conducted some liberal experiments selectively and locally. For example, the CCP implemented the competitive election of the grassroots officials in the party, combining both appointment and elections. It also conducted the execution of the permanent party congress, promoted the role of party representatives in the decision-making process, and attempted to decentralize the centralized party power through the separation of the decision making, execution, and supervision under the Party Congress. In particular, the CCP promoted institutionalizing different political opinions within the party, distinguishing the opinions and sects within the party (Chen, 2011).

In the process of party elections, the CCP has also conducted several local experiments, such as the permanent representatives of the party congress, the term limit of party representatives, the principle of majority voting system, and the direct elections at the local level. At the same time, for over 60 years, the CCP's internal party elections have also begun to develop from appointments, applause approval, verbal votes, hands-on voting, and single-candidate elections to partial, limited, and short-term anonymous ballots, multi-candidate elections, public campaign, and direct elections (Yang, 2009). The 18th CCP's National Congress, which ended in November 2012, proposed the implementation of the representative system of the Party Congress. In fact, in 2011, the 10th Party Congress of Hunan Province has implemented a representative proposal system in which the delegates submitted a total of 229 proposals and filed 181 cases. At the 13th Party Congress in 2012, Zhejiang Province also implemented the proxy system for the representative of the Party Congress, clarifying that more than 10 representatives can submit a proposal to the Party Congress. In the previous elections of the city, county and township party committees in Zhejiang Province, the party congresses at all levels also implemented the representative proposal system (Cai and Wang, 2012).

However, the above-mentioned reforms have always been difficult to be expanded and sustained. It is so hard to implement competitive elections in line with democratic common sense, international rules, and world trends. The main reason is that the motivation of reform from the top leadership is insufficient, the pressure from the bottom is not enough, and the capability of balance is lacking. The election within the party is hard to directly relate to common people's daily life and social stability. Although "there are massive demands to vote among leading cadres within the party, the major leadership is creating the greatest resistance in opposition to the substantive and democratic elections in the party" (Chen, 2011).

\section{The Perceptions of Competitive Elections within the Chinese Communist Party}

According to the historical process and current situation of the above-mentioned CCP's democratic elections and the development of checks and balances, it is necessary to sort out and summarize the basic perceptions within the $\mathrm{CCP}$ and explore the greatest common denominator that can be accepted by the majority, aiming at determining the direction of future political reform.

The first basic perception is that democratic election within the CCP is the most urgent and inevitable choice. It is meaningless to debate whether or not the election is necessary or good thing ( $\mathrm{Yu}, 2006$ ).

Obviously, if the current CCP intends to stop all political reforms, it may lead to a coup; if the CCP attempts to stop the reform, it may cause social instability and internal chaos; and if peaceful reform is dead, then a violent revolution will arise. A scholar from Beijing (22-G-1) (the 22nd respondent answered the first question [1] on the seventh big question [G]), mentioned in the interview on December 8, 2012, that currently in China, violent revolution and peaceful reform look like two tigers that are fighting each other. No one knows which one will die and which one will prevail. In order to achieve political reform peacefully, we must take the competitive elections within the party as the starting point and regard the competitive election as the "fundamental system of democracy and dynamic mechanism" (Xia, 2013).

The painful and cruel history of CCP internal struggles reminds current rulers that democratic elections within the party may provide an institutional protection for the losers after the failure of intra-party fighting. When Lin Biao helped Mao Zedong get rid of Liu Shaoqi as a party opponent in 1966, Lin did not know that five years later, in 1971, he would suffer even greater defeat; when Hua Guofeng helped Deng Xiaoping defeat the "Gang of Four" in 1976, Hua became a similar victim less than five years later. In the same way, Zhao Ziyang accepted the senior leaders' instructions in 1986 to provide his cooperation and assistance persecuting Hu Yaobang. Three years later, Zhao disappeared from the central power and was under house arrest until he died. The ever-repetitive zero-sum game in party struggles should give an incumbent a serious warning: If there is no legal system to protect the different opinions of the party and if there are no competitive party elections, you and I tomorrow may become 
yesterday's Liu Shaoqi, Lin Biao, Gang of Four, Hu Yaobang and Zhao Ziyang. The liberal or conservative political views should be quite normal, but the key is to establish and implement a fair, just and open procedure to allow different opinions within the party to be exchanged, debated and appealed. Therefore, in order to avoid the tragedies of cruel tortures and ruthless persecutions, it is necessary to give the dissidents within the party an institutionalized survival opportunity: you can live, but he is not necessarily dead.

In fact, the continued political struggle within the party is weakening the legitimacy of the CCP's ruling power, exhausting its dynamics, and destroying its reputations. Only democratic elections can save the CCP and revive Chinese civilization. The core of the soft power of any political party is political democracy, but the essential element of political democracy is competitive election (Hu, 2010) which has no variance in different systems, countries, and classes. Elections are the bottom line of democracy (Diamond, 1996). Vladimir Lenin as a founder of the Soviet Communist Regime also stated that everyone will probably agree that the "intensive democracy principle" should include the following two necessary conditions: first, complete democracy; second, all positions are elected (Lenin, 1987). Robert Dahl asserts that the gradual expansion of the rights of election has finally created a representative government including all the people, thus ushering in our concept of democracy today (Dahl, 1999). Therefore, only democracy can restrict both political power and economic capital. Otherwise, power will definitely form an alliance with capital (Tian, 2011).

In the interview, one official (1-G-1) said on March 15, 2002, "Capitalism has an American dream, but the Chinese power-capitalism has no future and no dream. The current confrontations caused by the gap between rich and poor and between fairness and injustice do not have adequate mechanisms for venting and complaining. As a result, the large number of migrants and intellectuals who are dissatisfied with the current situation are planning to create massive social crises. It is not just the crisis of trust, but a real threat to the CCP's foundation and governance."

The second basic perception about the intra-party reform is that the power originated from the people is a universal political idea, and democratic elections are the best way to implement this ideal.

For the CCP, all party members should be "people." The CCP's power is from its party members who offer the legitimacy to the CCP in leading the whole party. "Power from the people" is a necessary procedure to implement the principle of "power by the people." Given that 80 million members of the Communist Party cannot directly elect their leaders, it is necessary for CCP members to transfer their power to representatives through competitive elections and to authorize the representatives to follow four basic steps. The first is to elect representatives of the $\mathrm{CCP}$ to form a CCP member Congress; the second one is to ask the party representatives to elect the Central Committee of the CCP; the third one is to authorize the Central Committee of the CCP to elect the members of the Central Political Bureau and the members of the Standing Committee; and the fourth one is to let the Standing Committee members elect the general secretary as the top leader of the CCP. Thus, although power is authorized at various levels, the essence of the source of power is still controlled by every ordinary CCP member (Zhang, 2008).

In evaluating "the current operation of democratic centralism within the CCP," about $74 \%$ of the 22 interviewed Chinese officials and scholars believe that the biggest problem of the CCP is the lack of CCP members' rights of supervision, election, transparency, and speech see Table 1.

Table-1. The Statistical Table of Interviews on the CCP Reform (Question 1) (\%).

\begin{tabular}{|c|c|c|c|}
\hline $\begin{array}{l}\text { How do you evaluate the current operation of the democratic } \\
\text { centralism within the CCP? }\end{array}$ & Agree & Disagree & No Comment \\
\hline 1) Is the top leader's power too big? & 52.6 & 15.8 & 31.6 \\
\hline $\begin{array}{l}\text { 2) Is it difficult to implement effective supervision to the combined } \\
\text { disciplinary committee and the party committee? }\end{array}$ & 73.7 & 10.5 & 15.8 \\
\hline $\begin{array}{l}\text { 3) Party members don't have enough rights of supervision, election, } \\
\text { transparency, and speech. }\end{array}$ & 73.7 & 15.8 & 10.5 \\
\hline 4) Does the party often not operate under the Constitution? & 26.3 & 36.8 & 36.8 \\
\hline 5) Are the party's financial powers not subject to supervision? & 26.3 & 26.3 & 47.4 \\
\hline 6) Are the provincial and municipal level rights too large? & 10.5 & 15.8 & 73.7 \\
\hline 7) Others & O & O & $\mathrm{O}$ \\
\hline
\end{tabular}

Source: Based on the survey with Chinese scholars and officials on March 15, 2012 in China.

In this regard, a government-level departmental cadre (2-A-3) said on March 16, 2012 that "every party member is clear as to what their rights are. What is unclear is the result of the use of their rights." It demonstrates fear of exercising political rights. A departmental cadre who is engaged in party history research (9-A-3) believed on April 26, 2012 that "we can't blame an individual party member who had lack of rights to supervise and speech. They simply don't dare to express their honest opinion because they worry about their job security." There is also a retired 81-year-old cadre (12-A-3) who argued on May 26, 2012 that with respect to the rights to vote, "the candidates are prearranged and scheduled in advance, thus, the voting rights are in vain. Now the CCP emphasizes one voice, blocks the news, and does not allow a little noise. Therefore, how can we have the rights to know and access?" Also, in this retired official' view, "the freedom of speech must be punished, and once different opinions are expressed, the speeches will be locked up and may be sentenced as criminal. In particular, many senior comrades are seriously worried about the direction of the country and the benefits of the people." A retired cadre at the upper middle level of official ranking (13-A-3) also believed on May 28, 2012 that "the name of the party's suffrage is absolutely absent. As for the rights of supervision, know and speech are completely gone."

Another CCP official (17-A-3) said on June 6, 2012 that "the party members' rights to know are more critical, compared to their rights to supervision, voting, and speech. How can we guarantee supervision and speech without the right to know? At present, the right to know is very inadequate. There are some rights to vote for party members, but it is also limited. The 'fake' ballot can't express their wishes.” A CCP's scholar (20-A-3) said on June 20, 2012: "The rights to supervise, vote, know, and speak are mainly how to ensure transparent disclosure. It is 
necessary to formulate procedural regulations, and this stipulation cannot be a lip service. Some top leaders use procedural democracy in name to practice their substantial dictatorship."

The third basic understanding about intra-party democracy is that democratic elections can produce a benign and effective monitoring mechanism.

Theoretically, all elected CCP officials should accept people's checks because their power comes from the CCP members. Any CCP officials who evade, resist and suppress supervision should face the possibility of recall, impeachment and losing elections. Therefore, the democratic election within the CCP can naturally strengthen the democratic culture, implement decision-making democracy, promote transparency of party affairs, establish a regular report system of the Standing Committee to the National Committee, accept supervision, and be responsible for local party members. "The level of development of intra-party democracy determines the level of supervision within the party" (Gao, 2008). Moreover, competitive democratic elections can fundamentally smooth the relationship between officials and the public if the elected officials have power, responsibilities, and a greater driving force to connect to the people and serve the people. This will ultimately help save the legitimacy of the CCP officials in power (Gao, 2008).

When asked, "What is the easiest reform theme at the moment?" 53\% of participants chose "different elections at all levels of leaders," "direct election of party congress members" and "election method" reforms, including candidates' campaign and secret voting, etc. see Table 2.

Table-2. The Statistical Table of Interviews on CCP Reform (Question 3).

\begin{tabular}{|c|c|}
\hline $\begin{array}{l}\text { 3. If there are many problems in democratic centralism, what reforms can be carried out within } \\
\text { the party to transform the CCP from a revolutionary party to a modern ruling party? What is the } \\
\text { most easily reformed theme at the moment? }\end{array}$ & $\begin{array}{c}\text { Percentage } \\
(\%)\end{array}$ \\
\hline 1) Implement competitive elections of party leaders at all levels & 16 \\
\hline 2) Direct election of the Party Congress representatives & 32 \\
\hline 3) Transparency of the party affairs & 11 \\
\hline 4) Transparency of the party's finances & 5 \\
\hline 5) Disclosure of party members and cadres' private property & 26 \\
\hline 6) Reform election formats, including candidates' campaign, secret voting, etc. & 5 \\
\hline $\begin{array}{l}\text { 7) Resume the separation between party and government proposed by the CCP's 13th National Congress } \\
\text { in the late } 1980 \text { s? }\end{array}$ & 5 \\
\hline 8) Others & None \\
\hline
\end{tabular}

Source: Based on the survey with Chinese scholars and officials on March 15, 2012 in China.

This table shows that the current CCP officials and scholars mostly favor the reform of democratic elections within the party. The reason for this is that, according to a departmental official (3-C-6) on March 18, 2012, reforming the electoral system is operational and feasible with low political risk. An upper middle level official (1C-2) selected the option of direct election of the party congress representatives on the questionnaires above on March 15, 2012, but stressed: "Only direct elections are not enough. The party members need to have the rights to recall, appeal, and there must be a special agency to process the grievances."

The fourth basic perception about the intra-party democracy is that the CCP's identity has been diversified, and the interests of the CCP have been divided in light of dramatic socio-economic development. Therefore, the free election is necessary to select spokespersons who truly represent different opinions and interest groups, but the CCP must guarantee the legal status of these spokespersons.

In view of the existing dissident groups, most interviewed scholars believe that the CCP should allow party members to express different opinions and recognize different interests in order to promote the CCP's "transparency and inclusiveness" and reconcile the interests of broad communities and special groups (Wang, 2011). In fact, as early as 120 years ago, Friedrich Engels, one of the founding fathers of Communist ideas, addressed that the survival and development of each party is usually accompanied by the confrontations between the moderate and radical factions within the party. In Engels' view, the extremists will only promote the growth of this faction positively. In particular, Engels argues that the success of the labor movement is to sharply criticize the existing society, and criticism is the lifeblood of the workers' movement. Therefore, according to Engels, how can the labor movement itself evade criticism and prohibit the debate? Do we ask others to give ourselves freedom of speech, but eliminate others' freedom of speech? (Engels, 1995). Similarly, Mao Zedong used to state that it is common sense to have a party outside of the party and factions within the party. It is an Emperor's dictatorship to prohibit a party outside of the party. It is very strange if there are no factions within the party (The Literature Research Office of the CCP Central Committee, 2003).

In 2000, Jiang Zemin proposed the "three represents" and began to allow capitalists to join the CCP. This was a substantial revision to the CCP's basic principle because CCP's Constitution defines that "the CCP is the forerunner of the working class." However, the 18th Party Congress began to re-emphasize that the CCP simultaneously is the forerunner of the Chinese people and the Chinese nation," although meanwhile it is still representing the working class. The CCP is no longer just the vanguard of the working class (TCCoCCP, 2012). Class stratification and class division have become evidence in the CCP (Lewis and Litai, 2003; Dickson, 2004; Sato and Eto, 2008). As a result, the proletariat and the bourgeoisie have simultaneously become the main members of the CCP, and the bourgeoisie is increasingly leading the decision-making and soft power of the CCP. Consequently, the real proletariat and the working class are increasingly marginalized.

In particular, after the 16th National Congress of the CCP in 2002 and after the fourth generation of the CCP leaders proposed the development of a new strategy, the CCP has already emerged as a prototype of different interest groups, providing an organizational basis and ideological condition for their institutionalization of different interest groups (Zhang, 2000). For example, since 2002, Hu Jintao has proposed a different development strategy from Deng Xiaoping and Jiang Zemin, such as the scientific development and harmonious society. Therefore, extreme economic development at an extraordinary pace is no longer the top priority. Rich people cannot take all from poor people. They must let the poor share the pie. Moreover, the traditional mentality that 
stability means everything has made it difficult to guarantee sustainable and high-quality harmony in society. In this way, different development strategies and ideologies will inevitably affect and be reflected in different personnel arrangements, providing the possibility for the emergence of party factions.

In fact, since the 17th CCP's National Congress in 2007, the differences between the opinions and interests within the CCP have become increasingly clear. This difference is mainly reflected in the variances in their respective social and economic interests, focusing the conflict between capital and labor, developed coastal areas and developing heartland areas, and the central government and local governments. Specifically, the liberal group, similar to the US Democratic Party, advocates for social harmony, fairness and justice, fiscal subsidy to underrepresented areas, reducing farmers' economic burdens, regulating the stock market, emphasizing environmental protection, controlling housing prices, and caring for disadvantaged groups. In contrast, the conservative group advocates prioritizing economic development, dismantling urban resident housing for profitable real estate, confiscating rural land for economic investment, supporting capital interests, improving the investment environment, reducing central and administrative intervention, and promoting the free development of the stock market and the housing market, which are similar to the "Republicans" in the United States (Hong, 2007).

In this regard, Li Cheng also believed in 2007 that the existing political system is characterized by a "bipartisan" alliance formed by two major factions: one is the elitists and the other is the populists. Such a system would result in more transparent political lobbying, more legitimate factional politics, and more real elections ( $\mathrm{Li}$, 2007). Social and economic divisions within the CCP have become possible (Li, 2009).

In the interview, a member of the Chinese People's Political Consultative Conference (CPPCC) (7-D-1) who has been teaching at the university for 20 years argued on April 18, 2012 that "it is acceptable to have a transparent, institutionalized, and legalized party faction. At the current stage, this party faction issue is imminent. There is no need to cover up. In the future, party factions and differentiation will become more and more serious. Although the authority of the first generation of leaders like Mao Zedong was capable of eliminating different factions, now it is not possible. In fact, there are many existing factions now."

But a high-level cadre (20-D-1) said on June 20, 2012 that "it is impossible now to open, institutionalize, and legalize the party factions because it may cause the division of the party. But the CCP should allow appropriate competition within the party. Actually, competition and factions are connected each other. If there are more competitions, there will be more factions. Under the premise of norms, the CCP should provide a stage for appropriate competition, and relevant policies should be formulated within certain limits, certain conditions, and certain places."

The fifth basic perception about CCP's democratization is that the principle of a harmonious society and the human being-oriented society should also apply to the CCP. It must and should be implemented within the party, rather than just focusing on this principle for disadvantaged groups outside the party.

In theory, the essence of "human being-oriented" is that as long as he or she is a human being, whether he/she is a good person, a bad person or even a prisoner, he/she needs to be respected equally. However, at present, "human being-oriented" is more about emphasizing the poor, women, the disabled and the disadvantaged as human beings, and not treating the political opponents within the party as human beings. It seems that political opponents are neither humane nor dignified. Given the fact that the key factors affecting a harmonious society are both politics and the economy, caring for the poor can only promote a harmonious economic society. Only by treating the different political figures inside and outside the party can China build a harmonious political society. Therefore, the establishment of a benign competition system with humanity is necessary for the CCP's reconstruction and for strengthening the country's soft and smart power and long-term social stability.

Therefore, acknowledging different opinions and interest groups in the CCP can maximize the establishment and improvement of the supervision and balance mechanism within the CCP. Whether a party can be "great, glorious, and correct" depends to a large extent on whether there is a healthy and effective error correction mechanism within the party. Legalizing different groups and different opinions is the organizational guarantee of the party's internal error correction. Mao Zedong had a wise judgment on the regularity of the CCP's intra-party confrontations that would take place once every seven or eight years. This profoundly shows that the political ecosystem of the CCP determines the inevitability of an internal conflict within seven or eight years. However, the fundamental reason for this constant political fighting is that there is no legal mechanism in the party that legitimizes different interest groups; thus, this leads to a political earthquake in the party on a regular basis. If there is a legalized and institutionalized competition for different interests and opinions, then the tension within the party may be released and relieved at all times, and it is also possible to make the hidden rules a clear rule, turn the conspiracy to transparent struggle, and transfer the disorderly fighting to the ordered competition. It would help the party members and cadres reserve their different opinions and protect their rights to know, supervise, question and speech.

In the questionnaire survey of 30 Chinese officials and scholars, the author found that nearly $94 \%$ of the participants believed that the arguments of different views in the party were normal; $87.5 \%$ supported that different views need to be institutionalized; $81.25 \%$ believed that different political opinions need to be made public; $81.25 \%$ considered that the CCP should legalize and publicize different opinions within the party see Table 3 .

Based on the above five basic perceptions, the basic logic of competitive democratic elections within the CCP is that democracy must have elections, elections must be competitive, competition must demonstrate different political views, political opinions must be publicized, public campaign must be pre-organized, and then organizations will inevitably promote and maintain different interest groups. 
Table-3. The Statistical Table of Interviews on the CCP Reform (Questions 6, 7, 9 \& 10).

\begin{tabular}{|c|c|c|c|c|c|c|}
\hline \multirow{2}{*}{\multicolumn{3}{|c|}{$\begin{array}{l}\text { Question 6\#: Do you think that different views and arguments } \\
\text { in the party are normal? }\end{array}$}} & Yes & No & Not Clear & Others \\
\hline & & & $93.75 \%$ & $6.25 \%$ & $0 \%$ & $0 \%$ \\
\hline \multirow{2}{*}{\multicolumn{3}{|c|}{$\begin{array}{l}\text { Question } 7 \# \text { : If you think that it is normal to have different } \\
\text { opinions in the party, is it necessary to institutionalize and protect } \\
\text { such opinions? }\end{array}$}} & Yes & No & Not Clear & Others \\
\hline & & & $87.5 \%$ & $0 \%$ & $6.25 \%$ & $6.25 \%$ \\
\hline \multirow{2}{*}{\multicolumn{3}{|c|}{$\begin{array}{l}\text { Question 9\#: Do you think that the expression of different } \\
\text { opinions and interests in the party needs to be open and } \\
\text { institutionalized? }\end{array}$}} & Yes & No & Not Clear & Others \\
\hline & & & $81.25 \%$ & $12.5 \%$ & $0 \%$ & $6.25 \%$ \\
\hline \multirow[t]{2}{*}{$\begin{array}{l}\text { Question } 10 \# \text { : Best way } \\
\text { to handle dissidents } \\
\text { within the party? }\end{array}$} & $\begin{array}{l}\text { Establish a tolerant and relaxed } \\
\text { institutional environment }\end{array}$ & $\begin{array}{r}\text { Allo } \\
\text { exist } \\
\text { p }\end{array}$ & $\begin{array}{l}\text { them to } \\
\text { out never } \\
\text { olicize }\end{array}$ & \multicolumn{2}{|c|}{$\begin{array}{l}\text { Crack down } \\
\text { immediately to maintain } \\
\text { party unity and image }\end{array}$} & Others \\
\hline & $81.25 \%$ & & $\mathrm{O} \%$ & \multicolumn{2}{|c|}{$6.25 \%$} & $12.5 \%$ \\
\hline
\end{tabular}

Source: Based on the survey with Chinese scholars and officials on March 15, 2012 in China.

\section{Conclusion}

In light of the historical study and current understanding of the CCP's competitive elections, it is worth noting that the CCP has accumulated enough internal driving forces to advance its democratic reform. However, it is critical now to push the top leaders to take action in initiating and implementing political reform. Given the historical lessons in China, it is easier to maintain the status quo in the name of social stability led or misled by one authoritarian leader. After all, the mainstream of Chinese conservative culture and values still dominate over the majority of Chinese people's minds (Hong, 2015). Therefore, it is essential to study the specific problems of the current elections within the party and design action plans to implement the concrete and constructive steps in advancing the CCP's competitive elections to the next level.

\section{References}

Burns, J.P., 1999. The people's republic of China at 50: National political reform. The China Quarterly, 159(1): 580-594.Available at: https://doi.org/10.1017/s0305741000003349.

Cai, M. and J. Wang, 2012. The CCP decided to implement the party congress representative system to achieve a new level of democracy within the Party, Xinhua Net. Available from http://news.xinhuanet.com/18cpcnc/2012-11/11/c_113659670.htm [Accessed November 11].

Chen, H., 2011. Taking the theory of scientific development as the guide to actively and steadily promote the reform of the political system. The Frontline, 3(1): 1-9.

Dahl, R., 1999. On democracy. Translated by Li Baiguang. Beijing: The Commercial Press.

Deng, X., 1994. Selected works of Deng Xiaoping. Beijing: People's Publishing House, 1.

Diamond, L., 1996. Is the third wave over? Journal of Democracy, 7(3): 20-37.

Dickson, B.J., 2004. Beijing's ambivalent reformers. Current History, 103(674): 249-255.

Engels, F., 1995. Engers letter to trier in 1889. Selected works of marx and engels. Beijing: People's Publishing House, 4: 231.

Frechtling, J.A. and L.M. Sharp, 2007. User-friendly handbook for mixed method evaluations. Washington, D.C: National Science Foundation, Directorate for Education and Human Resources, Division of Research, Evaluation, and Communication.

Gao, X., 2008. On inner-party democracy II. China's Party and Government Cadres Forum, China, 1(1): 1-11.

Hong, Z., 2007. New Theory of the Standing Committee of the CCP's 17th National Congress. World Journal (Public Forum) (North America), October 30.

Hong, Z., 2015. The price of China's economic development: Power, capital, and the poverty of rights. Lexington, Kentucky: University Press of Kentucky.

Hu, J., 2007. Highly holding the great banner of socialism with Chinese characteristics and fighting for a new victory in building a well-off society in an all-round way-- Report at the CCP's.17th National Congress (October 15, 2007). Xinhua Ne.

Hu, J., 2012. Unswervingly advancing along the road of socialism with Chinese characteristics, fighting for building a well-off society in an all-round way--Report at the CCP's Eighteenth National Congress. Beijing: People Publishers. pp: 3-4.

Hu, W., 2010. The Chinese road to the development of democratic politics: The choice of the model of democracy within the party. Scientific Socialism, 1(1): 14-23.

Jiang, Z., 2002. To build a well-off society in an all-round way and create a new situation in the cause of socialism with Chinese characteristics (November 14, 2002). China Economic Net. Chinese Economics Publisher, China. Available from http://www.ce.cn/ztpd/xwzt/guonei/2003/Sljsanzh/szqhbj/t20031009_1763196.shtml.

Lenin, V., 1987. The complete works of Lenin. Beijing: People's Publishing House, 10.

Lewis, J.W. and X. Litai, 2003. Social change and political reform in China: Meeting the challenge of success. The China Quarterly, 176: 926942.Available at: https://doi.org/10.1017/s0305741003000559.

Li, C., 2007. China in the Year 2020: Three political scenarios. Asian Policy, 4: 17-30.Available at: https://doi.org/10.1353/asp.2007.000 1.

$\mathrm{Li}, \mathrm{C}$., 2009. Intra-party democracy in China: Should we take it seriously? China Leadership Monitor, 30(3): 1-14.

Liu, S., 1956. Political report of the CCP's eighth national congress. Beijing: People's Publishing House.

Nathan, A., 2003. Authoritarian resilience. Journal of Democracy, 14(1): 6-17.

People's Congress, 2018. The constitution of the people's Republic of China. Zhongguo Renda Net. China: Remin University Publisher. Available from: http://www.npc.gov.cn/npc/xinwen/2018-03/22/content_2052621.htm. Available from http://www.npc.gov.cn/npc/xinwen/2018-03/22/content_2052621.htm [Accessed March 6, 2019].

Qian, G., 2012. Intra-party democracy: The starting point for reform? New York Times Chinese Network, New York Times, Co., USA. Available from http://cn.nytimes.com/article/china/2012/09/24/cc24qiangang6/.

Sato, H. and K. Eto, 2008. The changing structure of communist party membership in urban China, 1988-2002. Journal of Contemporary China, 17(57): 653-672.Available at: https://doi.org/10.1080/10670560802253345.

Shi, T., 1990. The democratic movement in China in 1989: Dynamics and failure. Asian Survey, 30(12): 1186-1205.Available at: https://doi.org/10.1525/as.1990.30.12.00p0006k.

TCCoCCP, 1981. Resolution on several historical issues of the party since the founding of the people's republic of China. Xinhua Net. Xinhua News Agency, China. Available from http://news.xinhuanet.com/ziliao/2003-01/20/content_697994.htm [Accessed March 1, $2012]$.

TCCoCCP, 2004. Decision of the central committee of the communist party of China on strengthening the construction of the party's governing capability. (Adopted at the Fourth Plenary Session of the CCP 16th Central Committee). Xinhua Net.

TCCoCCP, 2005. Regulations on inner-party supervision of the communist party of China (Trial). Item One of the Chapter One. Xinhua Net. Available from http://news.xinhuanet.com/newscenter/2005- 01/16/content_2467829.htm [Accessed January 16, 2005].

TCCoCCP, 2007. Regulations on the protection of the rights of Communist Party members. China: China Network, China Network Publisher. 
TCCoCCP, 2008. Interim regulations on the tenure system of representatives of the national Congress of the CCP and local representatives. Xinhua Net, Xinhua News Agency, China. Available from http://news.xinhuanet.com/newscenter/2008$07 / 16 /$ content_8556621.htm [Accessed July 16].

TCCoCCP, 2012. Constitution of chinese communist party. Beijing: People's Publisher.

The Literature Research Office of the CCP Central Committee, 2003. 2nd Edn., Mao Zedong (1949-1976). Beijing: Central Literature Publishing House.

Tian, H., 2011. For the hope of democracy-Study on Hu Jintao's speech at the 90th anniversary of the founding of the party. China Election and Governance Network, the Carter Center, USA. Available from http://www.chinaelections.org/NewsInfo.asp?NewsID=211533 [Accessed July 27].

Wang, C., 2011. Accelerating the inner-party democracy. China Reform, $2(7): 1-3$.

Wu, B., 2011. Working Report of the Standing Committee of the Fourth Session of the 11 th National People's Congress. Wangyi News.

$\mathrm{Xi}$, J., 2010. Strongly establishing a correct world outlook on the concept of power--A speech at the opening ceremony of the central party school in fall 2010. Xinhua Net. Xinhua New Agency. Available from: http://news.xinhuanet.com/politics/2010-09/01/ C_12508694.htm. [Accessed September 1, 2010].

Xia, B., 2013. Exploring the democratic model of the world with Chinese characteristics-An interview with Hu Wei, Dean of the school of international and public affairs of Shanghai Jiaotong University. 10th Edn., The Liberation Daily, Shanghai, China, March 6.

Yang, L., 2009. The public and direct elections can check power and promote intra-party democracy. Liaowang Newsweek, November 27. pp:1-2.

Yu, K., 2006. Democracy is a good thing. China: People's Network, People's Daily Publisher.

Zhang, Q., 2000. Evolution without democracy: Toward a unified framework for understanding the success and failure of Chinese communism. Journal of Chinese Political Science, 6(2): 1-42.Available at: https://doi.org/10.1007/bfo2876921.

Zhang, S., 2006. The change of the political situation--the beginning and end of the seven thousand people's conference in China. Beijing: China Youth Press.

Zhang, S., 2008. On party affairs openness. New Oriental, 2(1): 18-24.

Zhao, Z., 1987. Advancing along the Socialist Road with Chinese Characteristics--Report at the CCP Thirteenth National Congress (October 25, 1987). The Database of the CCP National Congress. 